\title{
What is the Meaning of Anaphase-Promoting Complex 7 in Malignant Neoplasms?
}

\author{
Weon-Young Chang \\ Department of Surgery, Jeju National University School of Medicine, Jeju, Korea
}

\section{See Article on Page 139-145}

When malignant neoplasms are compared to normal cells or benign neoplasms, malignant neoplasms are found to have several characteristics: more rapid increase in size, anaplasia, invasion, and metastasis. Cytologic features of malignant neoplasm cells include increased nuclear size, pleomorphism, anaplasia, hyperchromatism, and bizarre mitoses. Two main theories are used to explain these characteristics of malignant neoplasms: gene-mutation hypothesis and aneuploidy hypothesis.

Hanahan and Weinberg [1] have proposed 6 hallmarks of cancer that include sustaining proliferative signaling, evading growth suppressors, resisting cell death, enabling replicative immortality, inducing angiogenesis, and activating invasion and metastasis. These hallmarks can explain well the gene-mutation hypothesis related to multistep tumorigenesis [2]. Molecular biologist Duesberg [3], who identified oncogene v-src, at first rejected the genemutation hypothesis. He supported the aneuploidy hypothesis, first proposed in 1914 by Theodor Heinrich Boveri, that cancer results from chromosome disruption rather than from a few gene mutations [4].

In this issue, Kim et al. [5] examined the relationship between anaphase-promoting complex (APC) expression and clinicopathological factors based on immunohistochemical staining. The authors' main conclusion was that the loss of APC expression in colorectal tumor tissues may be related with the risk for recurrence and poorer survival rate. The background of this study was the roles played by APC in mitotic cell-cycle progression. The in-

Correspondence to: Weon-Young Chang, M.D.

Department of Surgery, Jeju National University School of Medicine, 102 Jejudaehang-ro, Jeju 54987, Korea

Tel: +82-64-754-8101, Fax: +82-64-754-8004

E-mail: orkorea@jejunu.ac.kr

(C) 2017 The Korean Society of Coloproctology

This is an open-access article distributed under the terms of the Creative Commons Attribution NonCommercial License (http://creativecommons.org/licenses/by-nc/4.0) which permits unrestricted noncommercial use, distribution, and reproduction in any medium, provided the original work is properly cited. activation of APC is thought to be a cause of abnormal chromosome segregation that results in aneuploidy [6, 7]. Recently, many studies have discussed the relationship between chromosomal instability (CIN) and aneuploidy. Some studies have reported that CIN induces aneuploidy while others have reported that aneuploidy is not the result of malignant changes, but the cause of malignant changes $[1,8,9]$. Inactivation of the APC gene mediates chromosomal segregation and aneuploidy, so I think the importance of the APC gene is the point. A better understanding of the mechanism controlling the function of the APC gene will eventually lead to new strategies to combat cancer [10-12].

\section{CONFLICT OF INTEREST}

No potential conflict of interest relevant to this article was reported.

\section{REFERENCES}

1. Hanahan D, Weinberg RA. Hallmarks of cancer: the next generation. Cell 2011;144:646-74.

2. Fearon ER, Vogelstein B. A genetic model for colorectal tumorigenesis. Cell 1990;61:759-67.

3. Duesberg P. Chromosomal chaos and cancer. Sci Am 2007;296:529.

4. Harris H. Concerning the origin of malignant tumours by Theodor Boveri. Translated and annotated by Henry Harris. Preface. J Cell Sci 2008;121 Suppl 1:v-vi.

5. Kim IY, Kwon HY, Park KH, Kim DS. Anaphase-promoting complex 7 is a prognostic factor in human colorectal cancer. Ann Coloproctol 2017;33:139-45.

6. Park KH, Choi SE, Eom M, Kang Y. Downregulation of the anaphase-promoting complex (APC)7 in invasive ductal carcinomas of the breast and its clinicopathologic relationships. Breast Cancer Res 2005;7:R238-47.

7. Sudakin V, Chan GK, Yen TJ. Checkpoint inhibition of the APC/ $\mathrm{C}$ in HeLa cells is mediated by a complex of BUBR1, BUB3, CDC20, and MAD2. J Cell Biol 2001;154:925-36.

8. Duesberg P, Li R, Fabarius A, Hehlmann R. The chromosomal 


\section{Coloproctology}

basis of cancer. Cell Oncol 2005;27:293-318.

9. Meijer GA. Chromosomes and cancer, Boveri revisited. Cell Oncol 2005;27:273-5.

10. Bharadwaj R, Yu H. The spindle checkpoint, aneuploidy, and cancer. Oncogene 2004;23:2016-27.
11. Giam M, Rancati G. Aneuploidy and chromosomal instability in cancer: a jackpot to chaos. Cell Div 2015;10:3.

12. Thompson SL, Compton DA. Examining the link between chromosomal instability and aneuploidy in human cells. J Cell Biol 2008;180:665-72. 